Original Research Article

\title{
Effect of methyldopa and labetolol on fetal outcomes in hypertensive disorders of pregnancy
}

\author{
Mary Rohini Pentareddy ${ }^{*}$, Shailendra D. ${ }^{2}$
}

\begin{abstract}
${ }^{1}$ Department of Pharmacology, RVM Institute of Medical Sciences and RC, Laxmakkapally, Mulugu, Siddipet, Telangana, India ${ }^{2}$ Department of Pharmacology, Mediciti Institute of Medical Sciences, Medchal, Telangana, India
\end{abstract}

Received: 18 September 2017 Accepted: 27 October 2017

\section{*Correspondence to: Dr. Mary Rohini Pentareddy, Email: drmaryrohini@ yahoo.co.in}

Copyright: (C) the author(s), publisher and licensee Medip Academy. This is an openaccess article distributed under the terms of the Creative Commons Attribution NonCommercial License, which permits unrestricted noncommercial use, distribution, and reproduction in any medium, provided the original work is properly cited.

\begin{abstract}
Background: Hypertensive disorders represent the most common medical complication of pregnancy, with a reported incidence of 6-10\% and accounts for $15 \%$ of maternal mortality. Effective management of pregnancy induced hypertension is vital to improve maternal and foetal outcomes. As data are scarce on comparison of labetolol and methyldopa this study was undertaken. The objectives of the study were to evaluate effect of both drugs on fetal outcomes.

Methods: A comparative observational Study is designed. 30 patients who received Methyldopa and 30 patients who received Labetolol were included in the study. Methyldopa was started at a dose of $250-500 \mathrm{mg}$ thrice daily while Labetolol was started at a dose of 100-400mg twice daily. Patients were followed up during antenatal, intrapartum and postpartumperiod for perinatal outcomes.

Results: Intra Uterine Growth Retarded (IUGR) babies were 10\% in Methyldopa group and 6.66\% in Labetolol group. 20\% of new borns in Methyldopa group and $10 \%$ of new borns in Labetolol group got admitted in Neonatal Intensive Care Unit (NICU) because of distress. 13.3\% of new borns in Methyldopa group are small for gestational age(SGA), whereas only $3.33 \%$ in Labetolol group are small for gestational age.

Conclusions: Chances of development of IUGR, NICU admissions of neonates with respiratory distress syndrome and small for gestational age babies were more with methyldopa compared to Labetolol, but there was no statistically significant difference between two drugs.
\end{abstract}

Keywords: Fetal side effects, Labetolol, Methyldopa, PIH

\section{INTRODUCTION}

Hypertensive disorders are the most common medical complications of pregnancy (6-10\%) and a major cause of fetal morbidity and mortality (22\%). ${ }^{1}$

Women with gestational hypertension are at risk for progression to Pre-Eclampsia, Eclampsia, and abruption. The risks are decreased if patients are diagnosed at lower gestational age. ${ }^{1}$ Though hypertensive disorders in pregnancy cannot be prevented, early diagnosis and treatment helps in favourable maternal and fetal outcomes.

Antihypertensive drugs are often used to lower blood pressure with the aim of preventing this progression to adverse outcomes for the mother and the fetus. The benefits of antihypertensive therapy for mild to moderately increased blood pressure in pregnancy $(\geq 140 / 90$ and $\leq 160 / 110 \mathrm{mmHg}$ ), either chronic or de novo, have not been shown in clinical trials. 
Methyldopa is the most commonly used drug for Pregnancy induced hypertension, but it takes longer time to act. $^{2,3}$ In cases where monotherapy is inadequate to control blood pressure in patients with PIH other drugs have been used.

Advantage of Labetolol is that it is available in both oral and injectable formulations and onset of action is fast compared to Methyldopa.

Since the literature, effect of methyldopa and Labetolol on fetal outcomes is scarce, this study was undertaken to asses effect of above drugs on fetal outcomes in the treatment of mild to moderate pregnancy induced hypertension.

\section{METHODS}

This comparative, prospective, observational study was conducted in Gynaecology and Obstetrics Department of MediCiti Institute of Medical Sciences, over a period of one and half year (November 2012 to June 2014).

Size of the sample was 60 patients (30 patients in each group).

\section{Inclusion criteria}

- All pregnant women with mild to moderate hypertension (systolic BP 140-160mm of $\mathrm{Hg}$ and diastolic BP 90-110mm of $\mathrm{Hg}$ )

- $\quad$ Age of the patient between 18-35 years

- Primigravida or multigravida

- Vertex presentation

- $\quad$ Singleton pregnancy

\section{Exclusion criteria}

- $\quad$ Patient's age more than 35 years

- Severe pregnancy induced Hypertension (systolic BP $\geq 160 \mathrm{~mm}$ HG; diastolic BP $\geq$ to $110 \mathrm{~mm}$ HG)

- Severe Pre-eclampsia (severe hypertension with proteinuria $2+$ or more or $2 \mathrm{~g}$ or more / $24 \mathrm{hrs}$, headaches, visual disturbances, epigastric pain)

- Chronic hypertension

- Multiple pregnancy

- $\quad$ Bad Obstetric History

30 patients received methyldopa and 30 patients received Labetolol. Patients received treatment as per the as ses sment of the treating obstetrician.

Informed consent was obtained from all the patients before enrolment. Medical and obstetric history was taken, and physical examination was conducted at the time of initial recruitment.

Outcomes measured were Birth Weight of the babies, Apgar score at one minute and 5 minutes, all other perinatal outcomes like Intra Uterine Growth Retardation,
Small for gestational age babies and admis sions into NICU due to distress were also considered.

\section{Statistical analysis}

Data were entered in MS excel 2007, same were exported into STATA (version 10). For normally distributed continuous data, comparis on for significance of difference were done by using;

- Student's unpaired t test was used for comparison of normally distributed continuous data between the two treatment groups.

- $\quad$ Categorical data were analyzed for as sociations using chi square test.

$P$ value $<0.05$ was considered statistically significant.

\section{RESULTS}

This comparitive study was carried out in obstetrics and gynaecology department in MediCiti institute of medical sciences, ghanpur, medchal. 30 patients receiving Methyldopa and 30 patients receiving Labetolol were included in this study.

Table 1 shows the comparison of birth weight $(\mathrm{kg})$ between two groups of patients studied. The Mean birth weight was similar between two groups $(\mathrm{P}$ value $=0.409$. Majority of newborns, $40 \%$ in Methyldopa group and $56.66 \%$ in Labetolol group weighed between $2.6-3 \mathrm{~kg}$.

Table 1: Comparis on of birth weight between two groups.

\begin{tabular}{|lll|}
\hline Weight & Methyldopa & Labetolol \\
\hline$<2.5 \mathrm{~kg}$ & 12 & 9 \\
\hline $2.6-3.5 \mathrm{~kg}$ & 18 & 21 \\
\hline total & 30 & 30 \\
\hline Mean birth wt & $2.649 \pm 0.433$ & $2.731 \pm 0.318$ \\
\hline P value & 0.409 & \\
\hline
\end{tabular}

Apgar score at 1 minute was 6 in 5 new borns in Methyldopa group and 1 new born in Labetolol group. There was no difference between two groups $(\mathrm{P}$ value= 0.062) statistically (Table 2).

\section{Table 2: Comparison of Apgar score at 1 minute in} both groups.

\begin{tabular}{|lll|}
\hline Apgar Score & Methldopa & Labetolol \\
\hline 6 & 5 & 1 \\
\hline 7 & 13 & 12 \\
\hline 8 & 12 & 16 \\
\hline 9 & 0 & 1 \\
\hline P Value & 0.062, Non Significant \\
\hline
\end{tabular}

Table 3 shows Apgar score at 5 minutes. 9 new borns in Methyldopa group and 4 new borns in Labetolol group has 
Apgar score of 8 after 5 minutes. Majority of new borns 14 $(46.66 \%)$ in Methyldopa group and $18(60 \%)$ in Labetolol group had Apgar score of 10 . There was no statistically significant difference between two groups ( $\mathrm{P}$ value 0.155 ).

Table 3: Comparison of Apgar score at 5 minutes in both groups.

\begin{tabular}{|lll|}
\hline Apgar score at $\mathbf{5}$ mins & Methyldopa & Labetolol \\
\hline 8 & 9 & 4 \\
\hline 9 & 7 & 8 \\
\hline 10 & 14 & 18 \\
\hline P Value & 0.155, & Non Significant \\
\hline
\end{tabular}

Table 4 shows the comparison of perinatal outcome between two groups of patients studied. IUGR were $10 \%$ in Methyldopa group and 6.66\% in Labetolol group. 20\% of new borns in Methyldopa group and $10 \%$ of new borns in Labetolol group got admitted in NICU because of distress. 13.3\% of new borns in Methyldopa group are small for gestational age, whereas only $3.33 \%$ in Labetolol group are small for gestational age. There was no difference between two groups statistically. ( $\mathrm{P}$ value $0.054)$.

Table 4: Comparison of peri-natal outcomes between two groups.

\begin{tabular}{|lll|}
\hline & Methyldopa & Labetolol \\
\hline Normal & 19 & 25 \\
\hline IUGR & 3 & 2 \\
\hline NICU Admissions & 6 & 3 \\
\hline SGA & 4 & 1 \\
\hline P Value & 0.054 & \\
\hline
\end{tabular}

\section{DISCUSSION}

Hypertensive disorders seem to complicate approximately $10 \%$ of pregnancies and are important causes of maternal and fetal morbidity and mortality. ${ }^{1}$ The major goal of antihypertensive medication was to prevent adverse outcomes for the mother and fetus.

Table 5: Comparis on of mean birth weight with previous studies.

\begin{tabular}{|llll|} 
Drugs & $\begin{array}{l}\text { Present } \\
\text { study }\end{array}$ & $\begin{array}{l}\text { Verma, } \\
\text { et al }\end{array}$ & $\begin{array}{l}\text { Qarmalawi, } \\
\text { et al }\end{array}$ \\
\hline Methyldopa & $2.649 \pm 0.433$ & $2.6 \pm 0.36$ & $2.77 \pm 0.15$ \\
\hline Labetolol & $2.731 \pm 0.318$ & $2.5 \pm 4.3$ & $3.00 \pm 0.15$ \\
\hline
\end{tabular}

Table 5 shows that mean birth weight of newborns did not differ in two groups. In the present study the mean birth weight was $2.649 \mathrm{~kg}$ in Methyldopa group and 2.731 in Labetolol group, there was no statistically significant difference between two groups $(\mathrm{P}$ value $=0.693$ ). Present study findings were comparable with the study of Qarmalawi et al, where the Mean birth weight in Labetolol group was $3 \mathrm{~kg}$ and $2.77 \mathrm{~kg}$ in Methyldopa group. ${ }^{4}$
In Verma et al, study Mean birth weight of Methyldopa group was more than Labetolol group..$^{5}$ The Mean birth weight of the present study was also comparable with the studies of Plouin et al, Lamming et al. ${ }^{6,7}$

\section{Apgar score}

There was no statistically significant difference between the two groups regarding Apgar Score at 1 minute ( $\mathrm{P}$ value $=0.062$, Non significant).

There was no statistically significant difference between the two groups regarding Apgar Score at 5 minutes ( $P$ value $=0.155$, Non significant).

These findings were similar to Lamming et al, and Qarmalawi et al, where there was no statistically significant difference between two groups.

Table 6 shows that 3 patients among the Methyldopa group and 2 among the Labetolol group developed IUGR (P value $=1$, Non significant). There was no significant difference between the two groups in the development of IUGR.

Table 6: Comparis on of peri-natal outcomes with previous studies.

\begin{tabular}{|lllll|}
\hline \multicolumn{3}{|c}{ Present study } & Molvi S, et al \\
\hline Drugs & Methyldopa & Labetolol & Methyldopa & Labetolol \\
\hline $\begin{array}{l}\text { N, \% } \\
\text { of }\end{array}$ & $3(10 \%)$ & $\begin{array}{l}2 \\
(6.66 \%)\end{array}$ & $18 \%$ & $28 \%$ \\
IUGR & & $(6.6)$ & \\
\hline
\end{tabular}

Findings in the present study were comparable with the studies of Molvi et al, Plouin et al, Qarmalawi et al Lamming et al. ${ }^{8} 4$ patients in the Methyldopa group delivered SGA babies while only 1 patient in the Labetolol group delivered SGA baby $(\mathrm{P}$ value $=0.35$, Non significant). There was no statistically significant difference between the two groups in having babies with SGA.

6 new borns, in the Methyldopa group were admitted in the NICU with RDS and 3 newborns in the Labetolol group were admitted in the NICU with RDS. There was no difference between the 2 groups statistically, as regards to NICU admissions ( $\mathrm{P}$ value $=0.47$, Non significant $)$.

These findings were supported by previous studies by pickles et al, plouin et al, and walker et al, who have found no difference between two groups statistically. ${ }^{9,10}$

Limitations of the study was smaller sample size and single centre study.

\section{Recommendations}

The results of this study need to be confirmed in multicentre studies with large sample size. 


\section{CONCLUSION}

There was no significant difference in the Mean birth weight of the babies and Apgar Score at 1 minute and 5 minutes.

Chances of development of IUGR, NICU admissions of neonates with respiratory distress syndrome and small for gestational age babies were more with methyldopa compared to Labetolol, but there was no statistically significant difference between two drugs.

The low incidence of maternal and fetal side effects together with excellent perinatal outcome confirms Labetolol suitability for use during pregnancy.

Funding: No funding sources

Conflict of interest: None declared

Ethical approval: The study was approved by the Institutional Ethics Committee of Mediciti Institute of Medical Sciences

\section{REFERENCES}

1. National High Blood Pressure Education Program: Working Group Report on High Blood Pressure in Pregnancy. Ame J of Obs \& Gyn. 2000;183:51.

2. Cochrane study group Magee L, Duley L. Oral betablockers for mild to moderate hypertension during pregnancy. Cochrane Database of Systematic Reviews. 2003;3:CD002863.

3. Goodman \& Gilman's the pharmacological basis of therapeutics; $11^{\text {th }}$ Ed. 2006:32.

4. El-Qarmalawi AM, Morsy AH, Al-Fadly A, Obeid A, Hashem M. Labetolol vs Methyldopa in the treatment of pregnancy-induced hypertension. Int $\mathbf{J}$ of Gyn\& Obs. 1995;49:125-30.
5. Verma R, Lahon K, Tonpay SD, Kale VJ, Jain DK. A comparative randomised controlled parallel group study of efficacy and tolerability of Labetolol versus Methyldopa in the treatment of new onset hypertension during pregnancy. International Journal of Life Science \& Pharma Research. 2012;2(1).

6. Plouin PF, Breart G, Maillard F, Papiernik E, Relier JP. The Labetolol Methyldopa Study Group. Comparis on of antihypertensive efficacy and perinatal safety of Labetolol and Methyldopa in the treatment of hypertension in pregnancy: a randomized controlled trial. British J of Obs and Gyn. 1988;95:868-76.

7. Lamming GD, Symonds EM. Use of Labetolol and Methyldopa in pregnancy induced hypertension. British J of Cli Pha. 1979;8:217S-22S.

8. Molvi SN, Mir S, Rana VS, Jabeen F, Malik AR. Role of antihypertensive therapy in mild to moderate pregnancy-induced hypertension: a prospective randomized study comparing Labetolol with methyldopa. Archives of Gynecology and Obstetrics. 2012;285(6):1553-62.

9. Pickles CJ, Symonds EM, Pipkin FB. The fetal outcome in a randomized double-blind controlled trial of Labetolol versus placebo in pregnancy-induced hypertension. British J of Obs \& Gyn.1989;96:38-43.

10. Walker JJ, Crooks A, Erwin L, Calder AA. Labetolol in pregnancy induced hypertension. Fetal and maternal effects. In: Riley and Symmonds (eds). The investigation of Labetolol in the management of hypertension in pregnancy. Excerpta medica, Amsterdam. 1982:148-60.

Cite this article as: Pentareddy MR, Shailendra D. Effect of methyldopa and labetolol on fetal outcomes in hypertensive disorders of pregnancy. Int J Basic Clin Pharmacol 2017;6:2832-5. 